\title{
Systems Thinking in a Second Grade Curriculum: Students Engaged to Address a Statewide Drought
}

\author{
Margaret Sauceda Curwen ${ }^{1 *}$, Amy Ardell ${ }^{1}$, Laurie MacGillivray ${ }^{2}$ and Rachel Lambert ${ }^{3}$ \\ ${ }^{1}$ Attallah College of Educational Studies, Chapman University, Orange, CA, United States, ${ }^{2}$ College of Education, University \\ of Memphis, Memphis, TN, United States, ${ }^{3}$ University of California Santa Barbara Gervitz Graduate School of Education, Isla \\ Vista, CA, United States
}

Faced with issues, such as drought and climate change, educators around the world acknowledge the need for developing students' ability to solve problems within and across contexts. A systems thinking pedagogy, which recognizes interdependence and interconnected relationships among concrete elements and abstract concepts (Meadows, 2008; Senge et al., 2012), has potential to transform the classroom into a space of observing, theorizing, discovering, and analyzing, thus linking academic learning to the real world. In a qualitative case study in one school located in a major metropolitan area in California, USA teachers and their 7-and 8-year-old students used systems thinking in an interdisciplinary project-based curriculum. Through reflection and investigations, students devised solutions and used innovative approaches to publicly

Edited by:

Gary James Harfitt, University of Hong Kong, Hong Kong

Reviewed by:

Barry J. Graff,

Brigham Young University, United States

Luciana Venâncio,

Universidade Federal do Ceará, Brazil

*Correspondence:

Margaret Sauceda Curwen mcurwen@chapman.edu

Specialty section:

This article was submitted to

Teacher Education,

a section of the journal

Frontiers in Education

Received: 13 July 2018 Accepted: 26 September 2018 Published: 09 November 2018

Citation:

Curwen MS, Ardell A, MacGillivray L and Lambert $R$ (2018) Systems

Thinking in a Second Grade

Curriculum: Students Engaged to Address a Statewide Drought.

Front. Educ. 3:90 engage peers and family members in taking action to address an environmental crisis.

Keywords: systems thinking, critical thinking, critical pedagogy, elementary school children, contructivism, primary grades, literacy, ecoliteracy

"... [I]f we have the deep ecological experience of being part of the web of life, then we will (as opposed to should) be inclined to care for all of living nature. Indeed, we can scarcely refrain from responding in this way." (Capra and Luisi, 2014, p. 15)

Drought is an issue impacting the entire world. Reports often focus on specific countries, such as the crisis situation in Somalia where after 3 years of little rain there is increasing disease, malnutrition, and food scarcity (Mapping the Devastation of Somalia's Drought, 2018) and in Zimbabwe, where decades of drought conditions are causing the disappearance of medicinal plants relied upon by those living in rural areas (Mambondiyani, 2017). Global impact has been realized by the lost potential of resources. For example, the World Bank recently reported that droughtdepleted crops could have fed more than 80 million people every day for a year (Elliott, 2017). In response to the sheer number of extreme situations, the United Nations has announced a goal to achieve "universal, safely managed water and sanitation services by 2030" (Garrick et al., 2017, p. 1003). Unfortunately, the cost of such an endeavor has been estimated to be 114 billion U.S. dollars a year in capital expenditures (Garrick et al., 2017). This global effort to prioritize access to clean water reflects increasing awareness that environmental issues, including water shortages, have social consequences (McKibben, 2012; Wolf, 2012; Habiba et al., 2013; World Water Council, 2018). These might include social inequality, food scarcity, and disease, all complex issues which must be addressed on a global level (Capra and Luisi, 2014).

From 2009 to 2015, the state of California in the United States experienced the worst drought in doi: 10.3389/feduc.2018.00090 
and cities was not easy (Skelton, 2014). Yet, at one school located in a major metropolitan area, we have observed second grade teachers and their 7- and 8-year-old students use systems thinking throughout the curriculum to investigate water use and take actions to raise conservation awareness in their community. In this paper, we ask, "How do primary grade teachers and their students at one school apply a systems thinking perspective to the California drought in order to develop solutions with respect to water conservation?" This research is part of a broader investigation into teachers' systems thinking pedagogy and professional development that is designed to be constructivist and project-based.

Briefly, systems thinking is the understanding of interrelated and interdependent networks (Wheatley, 2006; Senge, 2007; Meadows, 2008; Capra and Luisi, 2014). It has been used to understand environmental, social, and economic issues and is relevant to our work as educators. The acknowledgement of the need for this kind of thinking has been codified recently in Kindergarten-12th grade standards in the United States through the Next Generation Science Standards, adopted by 42 of 50 states. These new skill sets require a pedagogical approach that is interdisciplinary and evokes critical thinking and problem solving (Stribbe, 2009).

Achieving these goals is possible through the application of systems thinking to the curriculum (cf. Strachan, 2009). This perspective connects social justice, economic prosperity, and environmental protection with workable and creative solutions (Capra, 1996; Strachan, 2009). When solutions to a global environmental issues such as climate change are contested by U.S. policymakers (Layton, 2015), understanding the consequences of human interaction with the environment and subsequent decision-making is critical (Capra and Luisi, 2014). Schools can play a key role in cultivating children's "systems view of life" (Capra and Luisi, 2014) for a life-long orientation to their world (Ben-Zvi Assaraf and Orion, 2005). Furthermore, developing children's systems thinking ability can "make visible...those conflicts that arise around shared resources for which everyone is mutually responsible" (Senge et al., 2012).

\section{PERSPECTIVE}

To gain insight into teachers' and young children's exploration of an ecological concern, we engaged with two complementary theoretical approaches. The first overarching framework is systemic sustainability education (Davis et al., 2015). It describes the evolution of pedagogy and learning from a traditional, individualistic, and linear approach into a more holistic and non-linear way of understanding the world. This framework encompasses other emerging educational theories including systems thinking-the second framework-that capture the multiple, interconnecting, and interdisciplinary systems that are interdependent and inform one another (Meadows, 2008; Senge et al., 2012; Capra and Luisi, 2014). Weaving these perspectives provides the backdrop for systems thinking within an educational setting, such as a classroom or school (Senge et al., 2012). It provides insight into possibilities when children learn to view their world through a systems lens that allows them to identify and address the complexity of social and ecological concerns.

\section{Systemic Sustainability Education}

Since the emergence of modern schooling several centuries ago, many movements have been proposed and enacted. Four movements have risen to particular prominence, namely standardized education, authentic education, democratic citizenship education, and systemic sustainability education (Davis et al., 2015). Each movement has been driven by contextual historical and economic influences and prevailing societal views of teaching and learning. According to the authors, the standardized education moment beginning in the 1600s was shaped by the needs of the Industrial Age and views of rationalism and positivism. The focus was on the preparation of a ready workforce and, despite centuries of a changing world, practices, such as an emphasis on uniformity in curriculum and objectified facts are still dominant. The authentic education movement promulgated in the early twentieth century arose during a rise of the middle class and the philosophies of deconstruction and pragmatism. Subsequently, the third movement of democratic citizenship education began to emerge during the mid-to-late twentieth century as both civil rights movements and individuals' access to resources increased through the information age. Teaching practices then began to reflect critical pedagogy, conscientization (Freire, 1970/1996), learner scaffolding (Vygotsky, 1938/1987), and empowerment. The authors next introduce the term systemic sustainability education to describe an emerging fourth movement emanating from the 1990s. Its contextual basis includes developments in complexity science and nonlinear dynamics. A distinguishing feature of this movement is that it extends the preceding democratic citizenship education movement's characteristics of individual participation and conscientization to "encompass obligations to respect and protect the physicality of existence" (Davis et al., 2015, p. 185). Learners are expected to become global citizens in which one envisions her/his place in the human and non-human world.

Systemic sustainability education emphasizes the interdisciplinary connections in order to encourage innovation that can support long-term viability of both the human and the more-than-human on Earth (cf. concept of ecocentric advocated by Capra and Luisi, 2014) and "communal well-being" (Heath, 2013, p. 223). Davis, Sumara, and Luce-Kapler use key concepts to describe elements of effective learning environments. The first is that students engage in learning that has transphenomenal complexity, described as "a form or happening that can only be understood by looking across levels of organization" ( $p$. 178). The authors contend this understanding has been evolving with recent theories of complexity and networks and can be usefully depicted by levels that draw attention to the complex web of human existence. Furthermore, these levels are nested within one another not in discrete levels but in a "dynamic dance" of influence, which include but are not limited to biological, psychological, sociological, economic, political, cultural and environmental dimensions. Through these explorations at different levels, students develop fractal 
consciousness-described as a more expansive and complex view of the world-and come to identify a place for themselves to engage in it. These new understandings develop through a process of recursive elaboration, in which students revisit what they know with each new investigation, testing and revising their thinking. As Davis, Sumara, and Luce-Kapler assert, the shift from linear thinking to a more expansive awareness of one's world means that, "The project of education is now less about providing children with an imagined-to-be-fitting toolkit to 'set them up' for adult life and more about engaging them meaningfully and pragmatically in the shared world" (2015, p. 240). Teachers have a responsibility to extend the consciousness of learners (p. 216), as they are agents of change, able to transform the planet. Influential educators in this contemporary movement (e.g., Peter Senge, Sugatra Mitra, Nel Noddings, Parker Palmer) conceive the learner as active and a co-constructor of their learning in collaborative inquiry.

\section{Systems Thinking}

A system is conceived of as "an interconnected set of elements that is coherently organized in a way that achieves something" (Meadows, 2008, p. 11) and systems thinking as a "way of understanding these elements to achieve a desired result" (Meadows, 2008). Emerging in the 1920s from biological sciences and further developed in the "1930s by organismic biologists, Gestalt psychologists, and ecologists" (Capra and Luisi, 2014, p. 79), over the decades this perspective has gained traction in varied contemporary disciplines. Today it is the basis of many fields including environmental science (e.g., Meadows, 2008), organizational behavior (e.g., Meadows, 2008; Senge et al., 2012), engineering (Lammi and Becker, 2013), ecoliteracy (Goldman, 2012; Capra and Luisi, 2014), and design (Montana-Hoyos and Lenmire, 2011). The approach has informed middle- and highschool pedagogy (e.g., Ben-Zvi Assaraf and Orion, 2005; Gero and Zach, 2014). International education efforts to develop young children's cognitive capacity for systems thinking have incorporated tools, such as concept mapping (Brandstadter et al., 2012), interactive simulations (Sheehy et al., 2000; Evagorou et al., 2009), and inquiry-based teaching techniques (Koski and deVries, 2013). Typically, empirical studies conducted in the U.S. have examined children's and youth's understanding of systems thinking through short-term intervention lessons and computer simulations, often within the science curriculum (e.g., HmeloSilver et al., 2007; Hokayem et al., 2015; Danish et al., 2017) or systems-based protocols (Sweeney and Sterman, 2007). Rarely has systems thinking been applied in mathematics, social studies and language arts (for exceptions see classroom examples in Senge et al., 2012).

Systems are network of relationships (Capra and Luisi, 2014) and have feedback loops in which a system can adjust itself and respond accordingly. Systems thinkers may communicate their understandings of a specific system using tools, such as causal loops, feedback loops, and stock-and-flow diagrams to identify points of influence and leverage. In a learning organization, individuals can identify their reality and points of leverage (Senge, 2007) that interrupt, disrupt, or alter a system.
Systems thinking demands an understanding of the "big picture" in order to leverage change on social, economic, cultural, cognitive, and emotional states for a thriving twentyfirst century existence (Capra and Luisi, 2014). This process has the potential to transform the classroom into a space of observing, theorizing, testing, discovering, and analyzing, thus linking academic learning to the real world (Senge et al., 2012). Through rigorous and meaningful instruction teachers and students, positioned as co-researchers, can recognize systems interdependence and inter-connectedness. There is evidence that systems thinking is viable with young learners (Ben-Zvi Assaraf and Orion, 2005; Senge et al., 2012; Hokayem and Gotwals, 2016) but insights on its role, purpose, and function with younger elementary grade students are relatively new. For example, a research review of complex systems research in science education between 1995 and 2015 found that additional research is needed in school settings as well as with teachers and teaching practices (Yoon et al., 2017).

\section{CONTEXT}

Sycamore Elementary School is an independent progressive school located in California. The school has roots in philosophies of Dewey and Piaget, among others, with attention to critical thinking, creativity, interdisciplinarity and reflective practice. Such schools are positioned to be sites of pedagogical innovation as they are not subject to policy and accountability demands (Senge et al., 2012). While Sycamore's demographics are primarily white and economically upper-middle to upper class, central to the school's focus are issues of diversity and multiculturalism presented through classroom instruction and community involvement. The school promotes life skills of respect, tolerance, and collaboration, among others. Its focus on project-based learning is a context in which systems thinking is most likely to be successful (Forrester, in Senge et al., 2012, p. 269). There are $\sim 410$ students in Kindergarten through fifth grades. The class size is typically 20 students.

This case study is part of a broader study of the school's partnership with a local public school. For 3 years, teachers at the two schools shared a systems thinking consultant to develop and introduce systems thinking pedagogy to their students. This current account documents one grade-level teaching team at Sycamore School and their exploration of the ongoing statewide drought. Because each school, classroom and grade level team developed a systems thinking pedagogy within its unique sociocultural context, we have chosen to present the data as a series of case studies.

In year 1 (2014-2015) of this 3-year research project, Sycamore had five Kindergarten through second-grade teachers and 64 voluntary students participate in the study. Teachers' professional development support included in-class observations, coaching, and meetings tailored to each respective school culture, individual teacher needs, and classroom context. Each teacher, in consultation with the expert, developed systems curriculum. This paper documents one facet of the study that 
follows the Sycamore's drought investigation initiated in the second grade.

The second grade drought inquiry project began when one child noticed a leaky water pipe on the school campus that remained unrepaired, eventually leading to the overwatering death of the tree that had been planted decades before during the dedication of the school. During weekly grade-level meetings, the three second-grade teachers who already espoused constructivist, collaborative, and student-centered approaches, eagerly developed the vein of study and coordinated their respective classrooms' learning activities. Teachers' willingness to learn alongside their students in the water conservation study demonstrated their value in pursuing "projects for real world significance" (Forrester, in Senge et al., 2012, p. 270). After sharing her students' engagement during a professional development workshop, one second-grade teacher proudly noted, "The reason we signed up for this [profession] was to make a change in the world."

\section{METHOD AND DATA SOURCES}

This embedded multiple case qualitative design (Yin, 2014) included ongoing and recursive data collection for the broader study of systems pedagogy and teacher professional development. For this facet of the study, we examined how three Sycamore School second-grade teachers and their 44 participating students used systems thinking to address the current statewide environmental drought crises. Chapman University's Institutional Review Board approved this research. Written informed consent was obtained from all individual participants included in the study. Written informed consent was also obtained from the parents/legal guardians of all non-adult participants.

Over 7 weeks, the lead author used qualitative methods including: observations and field notes of 16 classroom systems lessons; four professional development after-school meetings and a full day professional development meeting held jointly with the co-participating public school; weekly informal interviews with participating teachers; and two formal audiotaped and transcribed interviews with the professional development consultant. Additional data sources included student individual and group work and professional development meeting minutes. Analytic notes after each observation documented key moments of systems thinking pedagogy and children's learning. Two research team members examined early findings of systems thinking (Senge et al., 2012). Using grounded theory and triangulating data, we took these instances and developed interpretive codes. We repeatedly honed our codes identifying patterns and anomalies within and across data (Creswell, 2012). These codes were then connected to systemic sustainability education's concepts of transphenomenal complexity, recursive elaboration, and teaching as the mediation of learners' extended consciousness (Davis et al., 2015). Bias was ameliorated by using protocols for classroom observation and formal interviews; having all research team members analyze and consider alternative explanatory frameworks to the phenomenon; and sharing ongoing findings at research conference presentations. As former primary grade classroom educators ourselves and currently university faculty in teacher education programs, we were simultaneously learning about systems thinking with these participants and documenting the process and outcome. Member checks with the three classroom teacher participants substantiated and enriched the research findings.

\section{RESULTS}

With teachers and students attuned to the concept of interrelating systems (Senge et al., 2012), the curriculum-science, social studies, math, and language arts - took on an interdisciplinary approach driven by student contributions. We present insight into how teachers and students: (1) cultivated an understanding of systems thinking; (2) applied systems thinking to the drought crisis; (3) fostered systems thinking through ongoing reflection and research; and (4) used innovative approaches in publicly engaging peers and family members.

\section{Cultivating Systems Thinking in the Classroom}

To develop familiarity with a systems thinking perspective, teachers began the year by examining alongside their students the various systems they encountered. Unlike traditional thematic units that tend to focus on content, systems pedagogy focuses on seeing "interconnectedness, the relationships that hold the elements together" (Meadows, 2008, p. 13). Developing an understanding that "everything is connected to everything else," the teachers engaged in identifying systems in children's daily experiences and meaningfully integrated children's ideas into their classroom learning. For example, a teacher might create a systems map with student-generated ideas about various school experiences such as classroom rules and the class garden. Other hands-on activities provided more concrete experiences for these primary grade learners. When students sat in a circle and tossed a ball of yarn from one student to another, they reflected on connections between their topics on their recently completed individual research reports. With the strands of yarn stretched between students and each topic written on a slip of paper taped onto the floor, the classroom floor was soon transformed into a web of connections. This concrete experience vividly placed the child's individual project into the realm of the classroom community's projects. Other curricular examples include a language arts literature study on fairy tales and a mathematics study on money. In short, systems thinking permeated the classrooms' teaching and learning environment.

Once a foundational understanding of systems thinking was established, teachers used scaffolding questions (Tharp and Gallimore, 1988) nudging students to: (a) evaluate principles for natural and human-made systems; (b) make distinctions between working and broken systems; and (c) identify factors that influenced a system; and (d) develop solutions to maintain a functioning system or repair a broken system. This understanding of "super-ordinate" characteristics (Boersma et al., 2011) was meaningfully reinforced into their classroom learning. Some classroom examples include: teacher- and student-created system maps around a literature text study. In these documents, 
a teacher would record students' ideas about the different types of systems within a text, such as the farm system and the water system in the classic American children's literature text Charlotte's Web (White, 1952). These system maps were not causal loops but suggested relationships that were interdependent and interactional (Meadows, 2008; Senge et al., 2012). Students' language was captured on charts that were posted on the classroom walls and thus available to be revisited often. Thus, the myriad of relationships-non-linear and expansive-generating from one or more systems became a classroom shared text and ongoing resource.

Another typical way systems thinking was being utilized was when a teacher purposefully paused and asked students to reflect on a disruptive classroom incident vis-a-vis their "classroom listening system." Through the teacher's promotion of this ongoing "active network of communication" (Capra and Luisi, 2014, p. 97), students evaluated their negative actions and assumed responsibility in altering their behavior to selforganize and maintain a dynamic classroom social balance. The role of observation and reflection is a key systems thinking component (Senge et al., 2012, p. 152). Such real-life application of systems to classroom routines helped students grasp the ideas of the "invisible fabric of interrelated actions" (Senge, 2007, p. 6) and more importantly, reflect upon their agentic role in the feedback loop. Once students had multiple experiences in talking about systems, they were poised to handle more complex issues.

\section{Connecting Systems Thinking to the Drought}

As previously mentioned, when a leaking school water pipe sparked students' discussion about water waste and the concern for the ongoing drought, the second-grade teachers quickly tapped into student interest and launched class-specific investigations into the on-going statewide drought's causes, implications, and encouraged children's agency in devising solutions. Through writing and social studies hands-on learning, teachers encouraged students to explore water's role in different domains of their lives. One class composed "Odes to Water," another class included drought stories when they created their online newspaper. Another class explored, argued, and negotiated an ideal community's various social institutions, resources, organization, and geographic features, such as a mountain range and water well to bring water to the community. With each discussion, they engaged in several iterations of a three-dimensional ideal community model. For example, after placing key buildings and institutions, such as apartments, a bowling alley, and a hospital, the students realized the transportation system was under-developed. They decided to tear down and re-construct their community, this time with a focus on community members' ease in access and navigation. Forrester has noted the value of revisiting ideas asserting, "to be innovative, one must be willing to make mistakes while searching for reasons and improvement" (in Senge et al., 2012, p. 273). Such concrete applications of systems thinking fostered students' critical skills of tolerating change, evaluating decisions, developing solutions, implementing ideas, and reflecting on their agentic role in the feedback loop (Senge et al., 2012).

\section{Fostering Reflection and Research Throughout the Curriculum}

By constantly considering the relationship of the drought to their collective lives, teachers and students incorporated the topic throughout the curriculum including language arts, science, social studies, math, and art. Representative example lessons demonstrated students' ability to think "forward and backward" from abstract to concrete (Boersma et al., 2011) and transcended temporal moments. In reading the American literature text Sarah Plain and Tall (MacLachlan, 1985), students noted the role of geography, particularly, the water system in the main character's early twentieth century American life. Students fluidly moved back and forth through time. Integrating social studies and math, one class investigated the amount of ink and water used in mailers and coupons, more commonly referred to as "junk mail." These mailings were viewed as a contributing factor to the drought because of the amount of water required in the printing process. During a 1-week period, children collected junk mail from their families, weighed it, and calculated how much water had been used. Some students proposed the solution to eliminate all junk mail. Others thought of their family members and neighbors who used coupons. They advocated for those homeowners who might find the mailers' content to be of value. Recognizing the competing group interests and perspectives (Capra and Luisi, 2014), children negotiated and compromised to develop solutions that met interests of different groups, such as learning about and publicly promoting a website community members could subscribe to that would diminish the amount of junk mail sent to their homes through the mail.

In another math investigation, students tracked their daily home water usage. These water audits included activities, such as brushing teeth, taking showers, doing laundry, and watering lawns. When second-grade teacher Betsy implemented Drought Reflective Science/Language Arts journals for her students, she was surprised by one child's response. In his journal, the child detailed a futuristic "Crazy Car" innovative design to scoop up curbside water, filter it, and rebottle it (see Figures 1, 2). The child was exhibiting imagination and care for the social good thus reflecting high quality critical thinking pedagogy (Giroux, 2014).

The water crisis also permeated the curriculum in one unexpected student-initiated manner. When a teacher asked students to create their own math games as an assessment, several groups of children collaborated to create their versions of a game titled "Escape the Drought" (Figure 3). These math experience games wove together water usage, turn-of the-century farm life accounts [gleaned from their literature book Sarah Plain and Tall MacLachlan, 1985] and the water cycle. A roll-of-the-dice affected the players' outcomes by subtracting gallons of water for human and economic necessities, such as water for putting out fires and thirsty cows. Conversely, water could be added through rain's natural replenishment. The youngsters implicitly drew attention to several key components in a stock-and-flow diagram systems tool: stock, input and output flows, converters, and balancing processes (Senge et al., 2012) and change over 


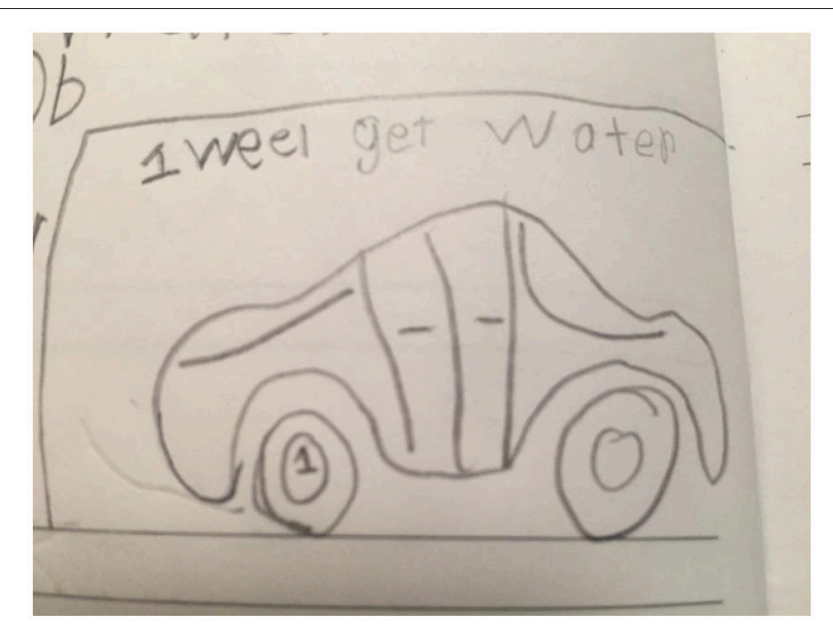

FIGURE 1 | Child's drawing of a futuristic vehicle to ease drought (Reads: 1 wheel [to] get water).

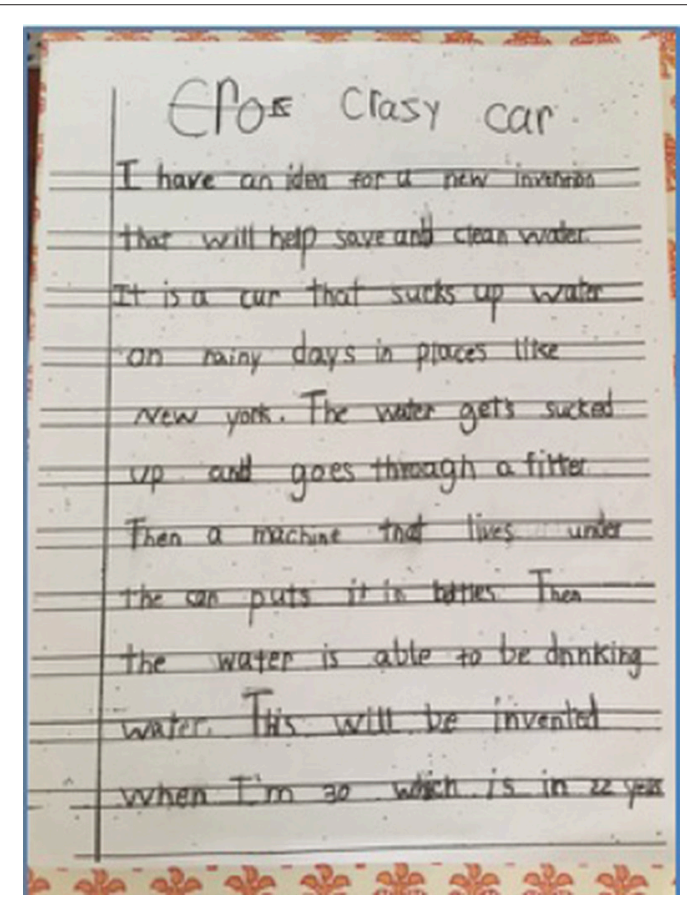

FIGURE 2 | Child's imagined future vehicle "Crazy Car" to ease drought.

time (Meadows, 2008). That is, by the accumulation of water (stock) and the natural rainfall resource (input flow) and the resulting balancing process between human, animal, and Earth's water usage needs (output flow) that altered the flow. Students who played their peers' math game responded to the consequence of a random dice throw that landed them on a specific input or output factor. These student-inspired math games were evidence of systems thinking evolving in the children's learning.

Through self-directed writing, a deepened appreciation for the importance of water in students' lives was fostered by one gradelevel teacher, whose students composed "Odes" that reflected on

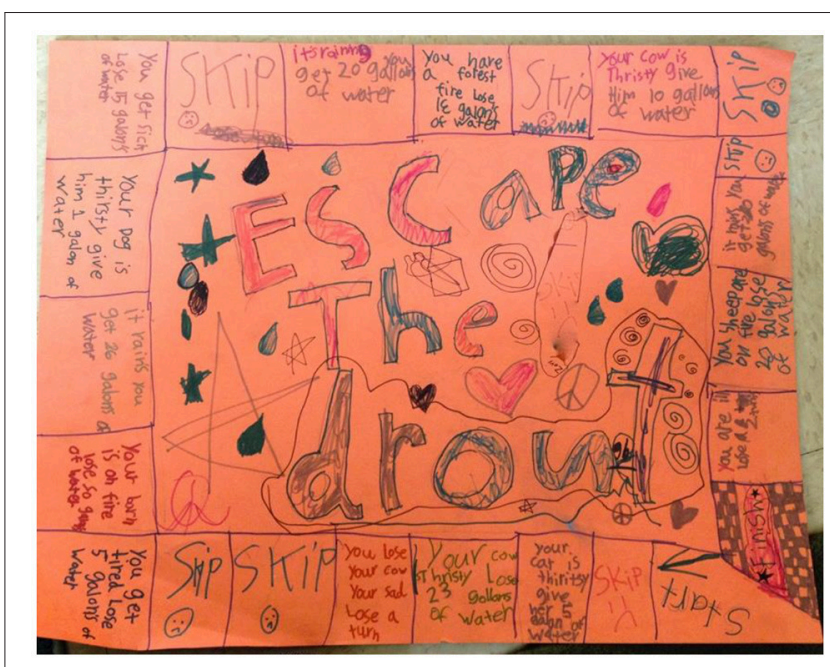

FIGURE 3 | "Escape the Drought" Math game incorporating input and output water flows.

the many aspects of water in their life. One afternoon during an unexpected light rain, the teacher held an impromptu writers workshop in which some students composed poetry as they sat outside to capture the moment. There under the school awning, students composed poems to the rain and later voluntarily shared them aloud in class. In schools, such relationships between curriculum, self, and the more-than-human world is vital in understanding the role of a global citizen (Davis et al., 2015).

In one science assessment, children were asked to create a systems map for an ocean animal of their choice. They were asked to link the animal to its habitat and food systems. Using their new vocabulary, each student created intricate webs and several students expanded these links to include the effects of human activity. One child's system map about the periwinkle snail linked to the "drought" and "shorter [indoor] showers" (Figure 4). When asked how shorter showers affected such a small creature, the child patiently explained to the researcher the consequence of water waste through long showers depleted the fresh water for all animals (The amount of water used for showers had been part of their earlier home usage water audit study). The second-grader demonstrated an understanding of human activity in relationship to the ocean's fragile ecosystem.

Unlike typical classroom learning that often consists of isolated facts (Senge et al., 2012), discrete curricular subjects (Davis et al., 2015), or abstractions (Meadows, 2008), these youngsters' math games, poetry, and science system maps captured their understanding of the complexity, interrelatedness, and social consequences of human behavior upon natural systems and resources.

\section{Using Innovative Approaches to Publicly Engaging Others}

Systems thinkers Capra and Luisi (2014) contend that organizing systems can be found everywhere and that, "Whenever we look at life, we look at networks." We saw evidence that the students intuitively recognized this concept as they studied 
their classroom social system and the way it was nested within multiple systems of school, family, and community. Students insisted on publicly sharing their knowledge by informing their school community and families of their efforts (Freire, 1970/1996) thereby increasing public accountability (Giroux, 2014) in conservation measures. Second-graders from one classroom posted drought awareness posters strategically around the school encouraging all Sycamore School students, teachers, and adult visitors to adopt a systems orientation and save water (Figure 5). Another classroom identified points of leverage, "the places where relatively small actions can produce relatively large results" (Senge et al., 2012, p. 126). Students devised a project to minimize their peers' school-wide water usage through time limits. Integrating art into this effort, one teacher guided her students to create timers consisting of small jars of a water, oil, and glitter mixture she found on Pinterest. Children then placed these 10- and 20-s timers throughout the school's water fountains and bathrooms with hand-written instructions on how to self-monitor water usage (Figure 6) while drinking water and washing hands. These projects demonstrated their understanding of how controlling output flows could help stabilize a natural resource (Meadows, 2008; Senge et al., 2012). During the home audit of water usage in another class, children reported their families' uneven response. While a heightened attention to water use motivated some siblings to shorten their showers, one parent doubted the accuracy of water usage statistics. At the end-of-the-year, the second-graders presented their research to students, teachers, and families during a school wide assembly. They identified leverage points, such as attention to excessive consumer consumption of mass-produced clothing, water waste and proposed solutions for "making the world a better place" (Strachan, 2009).

Yet another class eager to learn how community leaders were dealing with the environmental issues invited a local politician as a guest speaker. As Davis, Sumara, and Luce-Kapler note, educators need to be able to tap into and connect interests to others' expertise $(2015$, p. 187). In a question and answer session, the elected official spoke to the second graders about conservation in their neighborhood. After the politician left, the

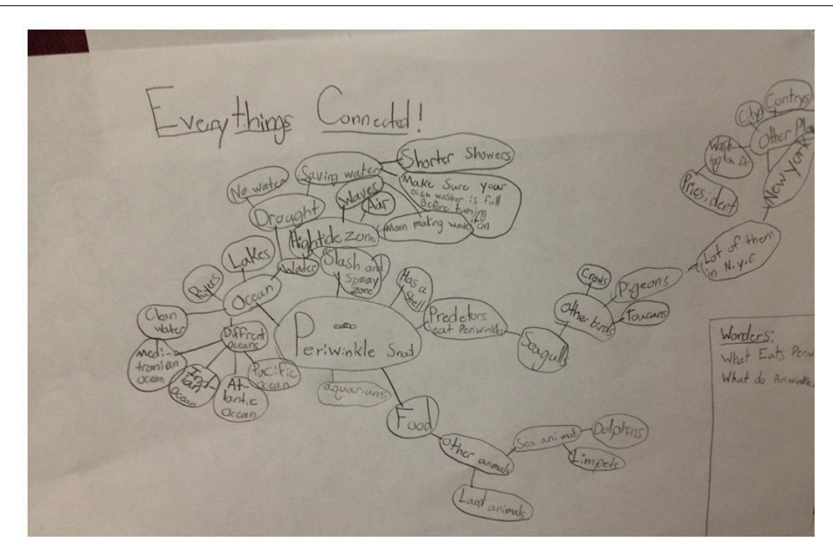

FIGURE 4 | One second-grader's science systems map on periwinkle snail. teacher helped extend students' thinking about the initial topic of community conservation efforts and guided their conversation. Students reflected on the interactions of various systemspollution, transportation, their literature text-and changes over time within a system. As was often the case, teacher and students referred back to the class-generated systems' principles chart that was posted on the wall. The system principles chart was a resource that allowed students to repeatedly review system characteristics and test their evolving theories of a system and of inter-related systems. With a bit of teacher prompting and attention to prior learning, the students teased out related systems of conservation, pollution, communication, and transportation.

Teacher: [The politician] was talking about a concern.

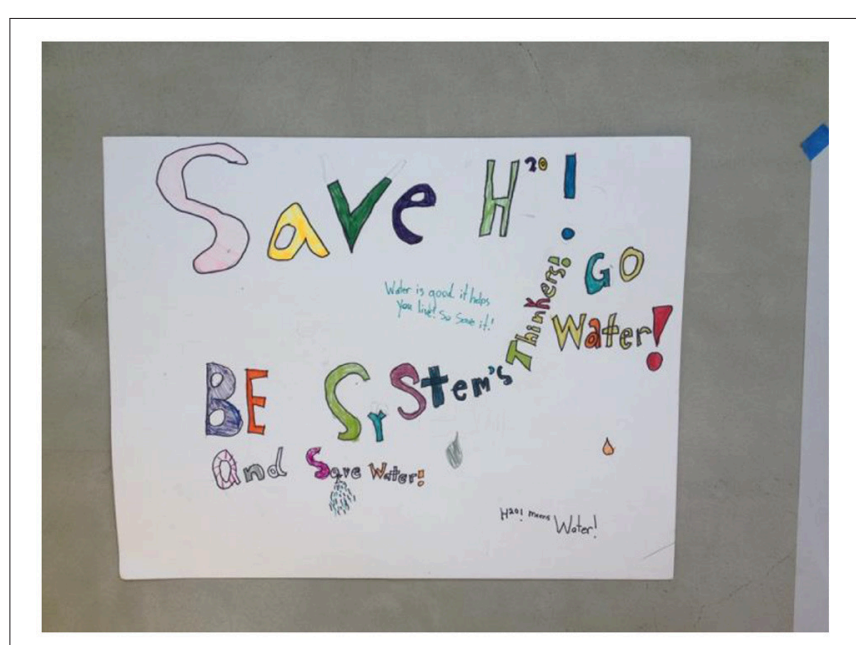

FIGURE 5 | Posters throughout school encouraging systems thinking.

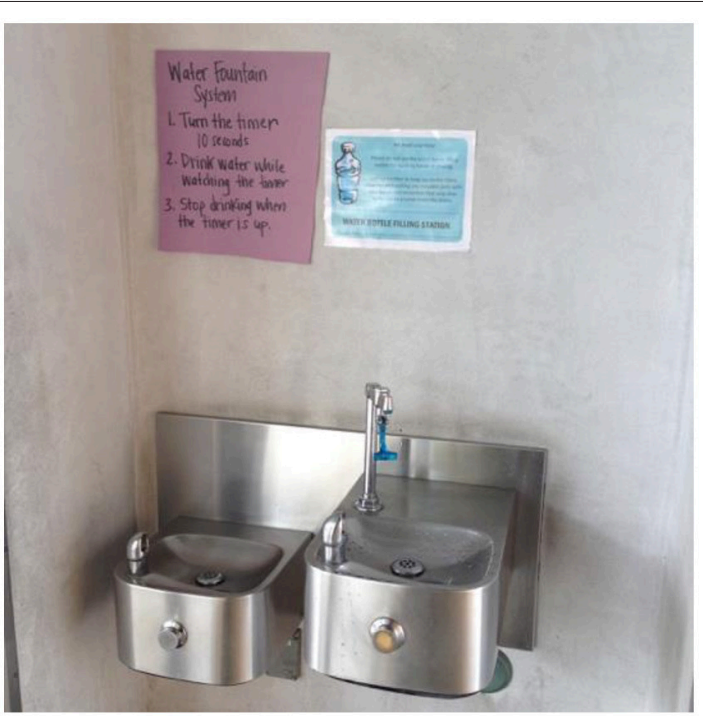

FIGURE 6 | Hand-written instructions prompting self-monitoring of water usage strategically placed at school's drinking faucets. 
Student 1: Planes from the [local] airport coming too close. It's too loud and it's polluting.

Teacher: Actually, it was about [the major airport] and people are concerned about planes and pollution.

Teacher: In the book [Caleb's Story MacLachlan, 2001] you read, where there are planes, you know systems change. [Points to one of the systems principles on chart.] What other systems may have changed? What else is different? What other changes have happened in transportation systems?

Student 2: Used to be farms and wagons.

Student 3: I'm reading... My mom is reading a series Narnia and some and some animals talk, for example, a horse doesn't know it's pulling a carriage but they know.

Student 4: Everything affects everything. We don't think about that a lot.

Student 5: I have a thing about planes that is disturbing. When it flies, it affects the atmosphere.

Teacher: We've thought about negative issues. Anything about positive [issues]?

Student 6: If you lived on Hawaii, you wouldn't be able to get there [without a plane].

Teacher: How have transportation changes helped our communities in some way?

Student 7: Planes can be useful to get places. When you use a plane it's a lot easier.

Teacher: Remember we talked about communication system. Student 8: Carrier plane or pigeon had to...... If we didn't have planes or cars, some people wouldn't have been discovered.

Student 4: It also helped because hydrogen cars help the water. I think [Student 9] said that they either take away or give something.

Student 9: If plane is high enough, it can go into the atmosphere.

In this vignette, the teacher provided an opportunity for children to recall their previous understanding of the principles underlying systems, their previous investigation of other systems and their connections to changes in systems that are constraints or affordances in human lives. Overall, when children had opportunity to reflect on their learning and take action, they demonstrated resiliency and possibility. These secondgraders actions disrupted the typical boundaries of classroom learning resonant with other children's critical literacy practices (Comber et al., 2001) and draw attention to the potential of systems thinking in elementary grades (Boersma et al., 2011).

\section{DISCUSSION}

The children in these classrooms support systems thinking researchers' assertions that 'most children... are natural systems thinkers, highly attuned to the interrelationships among nature, other people, emotions, thoughts, and themselves" (Senge et al., 2012, p. 125). Ultimately, students began to recognize their reality and consider their agency in providing solutions to a complex environmental problem. They developed a "heightened awareness that one's actions made a difference" (Davis et al., 2015, p. 186) by cultivating a systems thinking perspective in the classroom.

\section{The Transphenomemal Character of the Drought Exploration}

According to Davis et al. (2015), a transphenomenon is "a form or happening that can only be understood by looking across levels of organization" (p. 178). At Sycamore School, youngsters explored the complex system of the drought on multiple levels from neurological, to psychological, social, cultural, and ecological levels as depicted in Figure 7 below. On a neurological level, students were able to spend time understanding the concept of a drought and what significance it had to them. The teacher-directed drought system maps, and student-generated science systems were instances of recursive elaboration, which "strengthens neural pathways" (Davis et al., 2015, p. 215). On a psychological level, students' differential curricular engagement in the ongoing drought crises fostered evolving interpretations. Students gained a deeper understanding of the Earth's limited resources in math and of the consequences of human behavior on ecology. They understood natural resources as elements of human existence through math, literature, and science. Multiple entry points, the authors suggest "affords more flexible understandings" (p. 215). On a social level, students engaged with one another and collaborated in the posting of signs around the school, where to place their water-usage timers, integrating multiple perspectives in determining solutions for junk mail, and negotiating the needs of others in a model community. In creating their three-dimensional representation, children were comfortable with multiple iterations of their project as their thinking expanded. They handled the failure, revision, and starting-over process as an expected course of their learning.

On a cultural level, students engaged with the community and presented their solutions to the statewide drought to the rest of the school, family members, and other teachers who were in the audience. They sought the expertise of community leaders to further expand their understanding and contextualize their interest in water conservation with other ongoing community efforts. Finally, the students recognized the ecological consequences of human water consumption and climate change in their lifetime. They are aware that they need to change the world and furthermore, they feel capable of coordinating their efforts with others to address a complex problem. Unlike students who exercise linear thinking in traditional classrooms and focus on uniform expectations of a pre-set curriculum and objective knowledge, Sycamore School's second-graders were able to consider the past, present, and imagined future possibilities (Davis et al., 2015, p. 186). Students were becoming global citizens in "developing a sense of responsibility and efficacy for an interdependent world" (Senge et al., 2012, p. $566)$. 


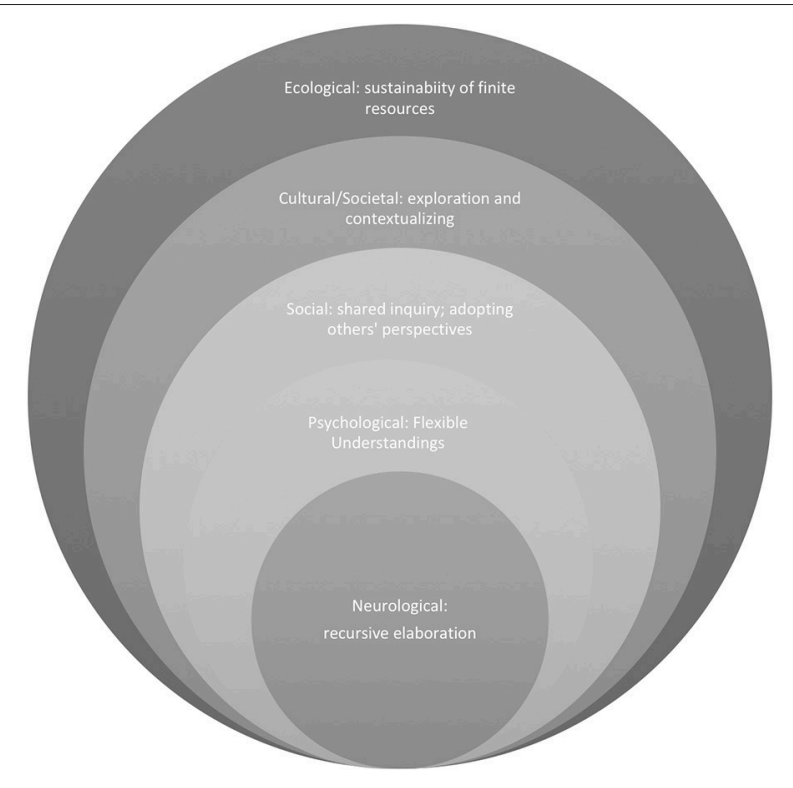

FIGURE 7 | Transphenomenal character of second-graders' drought exploration adapted from model of "Learning Systems," from Engaging Minds: Cultures of Education and Practices of Teaching, Chapter 4.1, by Davis et al. (2015). Figure used with permission by copyright holder Brent Davis.

\section{Teacher as an Enlarged Consciousness of the Learner}

The Sycamore School second-grade teachers cultivated a systems thinking perspective in their classrooms by continually drawing connections across the curriculum and in students' interactions. The role of the teacher in systemic sustainability education is to develop or enlarge the consciousness of the learner (Davis et al., 2015). This is achieved by providing ways for the individual to be engaged in multiple learning opportunities. At Sycamore School, the teachers took on the responsibility of "orienting attentions" (Davis et al., 2015, p. 217) by continually cultivating students' view of the world as a connection of interrelated systems. When the concern over the statewide drought arose, this perspective was naturally transferred into this arena. The teachers continually encouraged and invited them to think of others' perspectives. This focus complemented the school's overarching life skills of respect, caring for others, and cooperation. Adopting others' viewpoints was embodied in familiar teacher phrases such as " 'we' thinking and not 'me' thinking." It was an intentional effort by classroom teachers to use systems thinking to broaden students' engagement with the world outside the classroom walls and to recognize that they had agency in affecting change.

Systems thinking is a shift from traditional educational pursuits to holistic and non-linear ways of understanding the world (Capra and Luisi, 2014). As such, it compels educators, administrators and policy makers to avoid "thinking of the school as an isolated entity but as an interconnected set of processes and practices, linked by its nature both to the community around it and to the classrooms and individual learning experiences within it" (Senge et al., 2012, p. 15). Recursive elaboration (Davis et al., 2015) was evident as the teachers provided multiple opportunities for the children to engage, demonstrate, analyze, evaluate, and generate ideas. Children engaged in learning about the drought through literature, discussions, and real-life experiences. Children had hands-on opportunities to demonstrate and test their understanding of system elements and relationship within a larger system through the building of a three-dimensional classroom community and articulating their recognition of the statewide drought's patterns and relationships between limited natural resources and human consumption. Taking an agentic stance, they identified leverage points within the water cycle system, implemented solutions, and developed ideas shared with others about how individuals could affect change. The varied modes of engagement scaffolded learners' deep understanding of a system's "dynamic processes rather than the static structures" (Hmelo-Silver et al., 2007, p. 327).

Educators contend that a current Western educational paradigm of atomistic and reductionist curricular approaches needs to be transformed to holistic, environmental, systemsbased and eco-justice systems-based perspectives in which the individual recognizes self as intertwined in nested systems (Bowers, 2010; Cassell and Nelson, 2010). This study offers insights in how systems thinking encouraged these educators to develop students' critical thinking skills through understanding the interrelatedness and interconnectedness of the natural world and human activity. Energized by a purposeful interrogation into a contextually specific issue, such as the statewide drought, and by their understanding of how systems can be disrupted through feedback loops, these young children developed agency in devising solutions and then igniting environmental awareness in their wider community. Establishing a foundation of systems thinking in younger grades has the potential to lead to higher order thinking throughout their middle- and high school years (Ben-Zvi Assaraf and Orion, 2010; Hokayem et al., 2015). A systems approach has the potential to examine key social and environmental issues by telescoping between local and wider-arcing contexts and recognizing the inter-relatedness and interconnectedness among natural and human systems. Moreover, the desire by both the school to innovate this kind of practice along with a public-school partner, as well as students' interest in sharing their learning with a larger community audience, provides a mechanism for school curriculum to serve the public good in multiple ways. It heightens awareness about a key environmental issue while simultaneously offering concrete actions for people to take. In addition, it demonstrates the ways the public can benefit from the perspectives of some of the youngest citizens in our democracy.

\section{Implications for School Leaders}

This research documents the ways primary grade teachers and students actively take up competencies integral to recognizing and solving a real world complex problem (Sheehy et al., 2000). Systems thinking pedagogy was effective because of the support of the school administrators who were alert to teacher interest and responsive to changes in the curriculum. They ensured conditions for professional development and fostered internal and cross-school collaboration. First, administrators committed to the innovative pedagogy which is not often included in 
curriculum. A unique aspect in this study is that systems thinking pedagogy had been initiated and piloted by one of the second grade teachers with the coaching of a retired educator. When colleagues noticed changes in student engagement, they expressed an interest in similarly learning about this approach. Accordingly, the school sought outside funding to support the consultant in providing professional development and in-class coaching for an extended period of time. Research has shown that such coherence of learning activities (Opfer and Pedder, 2011) and focused and prolonged professional development are most effective (Desimone, 2009). Second, the school leaders provided opportunity for classroom teachers to dedicate time to learning how to create this innovative pedagogy and to articulate its relationship to ongoing school perspective on life skills. Third, school leaders provided time for teachers to interact with a neighboring school's teachers to share learning as well as time for teachers to reflect on their learning and collaborate with peers. In these ways, school leadership is critical in creating supports that allow classroom teachers and their students to tackle what systems thinking researchers refer to as wicked problems, such as the drought crisis. Such leadership promotes educators' and children's recognition of their own position within the larger

\section{REFERENCES}

Ben-Zvi Assaraf, O., and Orion, N. (2005). Development of system thinking skills in the context of earth system education. J. Res. Sci. Teach. 42, 518-560. doi: $10.1002 /$ tea. 20061

Ben-Zvi Assaraf, O., and Orion, N. (2010). System thinking skills at the elementary school. J. Res. Sci. Teach. 47, 540-563. doi: 10.1002/tea.20351

Boersma, K., Waarlo, A. J., and Klaassen, K. (2011). The feasibility of systems thinking in biology education. J. Biol. Educ. 45, 190-197. doi: 10.1080/00219266.2011.627139

Bowers, C. A. (2010). Educational reforms that foster ecological intelligence. Teach. Educ. Q. 37, 9-31.

Brandstadter, K., Harms, U., and Grobschedl, J. (2012). Assessing system thinking through different concept-mapping practices. Int. J. Sci. Educ. 34, 2147-2170. doi: 10.1080/09500693.2012.716549

Capra, F. (1996). The Web of Life: A New Understanding of Living Systems. New York, NY: Anchor Books/Random House.

Capra, F., and Luisi, P. L. (2014). The Systems View of Life. Cambridge: Cambridge University Press.

Cassell, J., and Nelson, T. (2010). Visions lost and dreams forgotten: environmental education, systems thinking, and possible futures in American public schools. Teach. Educ. Quart. 37, 179-197. doi: 10.2307/234 79466

Comber, B., Thomson, P., and Wells, M. (2001). Critical literacy finds a "place": Writing and social action in a low-income Australian 2/3 classroom. Elementar. School J. 101, 451-464.

Creswell, J. W. (2012). Qualitative Inquiry and Research Design: Choosing Among Five Approaches, $3 r d E d n$. Thousand Oaks, CA: Sage Publications.

Danish, J., Saleh, A., Andrade, A., and Bryan, B. (2017). Observing complex systems thinking in the zone of proximal development. Instruct. Sci. 45, 5-24. doi: 10.1007/s11251-016-9391-z

Davis, B., Sumara, D., and Luce-Kapler, R. (2015). Engaging Minds: Cultures of Education and Practices of Teaching, 3rd Edn. New York, NY: Routledge.

Desimone, L. M. (2009). Improving impact studies of teachers' professional development: toward better conceptualizations and measures. Educ. Res. 38, 181-199. doi: 10.3102\%2F0013189X08331140

Elliott, L. (2017), October 24. Food Ruined by Drought Could Feed More Than $80 \mathrm{~m}$ a Day, Says World BANK. In the Guardian. Available online at: https://www.theguardian.com/business/2017/oct/24/food-ruinedby-drought-could-feed-more-than-80m-a-day-says-world-bank world, and in doing so, fosters a greater commitment to global citizenry (Capra and Luisi, 2014).

\section{APPRECIATION}

The authors would like to thank the study's participants including: teachers, students, instructional coach, and administrators for sharing their classrooms, time, and insights with us.

\section{AUTHOR CONTRIBUTIONS}

MC, AA, and LM: substantial contributions to the conception or design of the work; MC and LM: the acquisition, analysis or interpretation of data for the work; MC, AA, LM, and RL: drafting the work or revising it critically for important intellectual content; MC, AA, LM, and RL: provide approval for publication of the content; MC, AA, and LM: agree to be accountable for all aspects of the work in ensuring that questions related to the accuracy or integrity of any part of the work are appropriately investigated and resolved.

Evagorou, M., Korfiatis, K., Nicolaou, C., and Constantinou, C. (2009). An investigation of the potential of interactive simulations for developing systems thinking skills in elementary school: a case study with fifth-graders and sixth graders. Int. J. Sci. Educ. 31, 655-675. doi: 10.1080/095006907017 49313

Freire, P. (1970/1996). Pedagogy of the Oppressed. New York, NY: Continuum.

Garrick, D., Hall, J., Dobson, A., Damania, R., Grafton, R. Q., Hope, R., et al. (2017). Valuing water for sustainable development: measurement and governance must advance together. Science 358, 1003-1005. doi: 10.1126/science. aao4942

Gero, A., and Zach, E. (2014). High school programme in electro-optics: a case study on interdisciplinary learning and systems thinking. Int. J. Eng. Educ. 30, 1190-1199.

Giroux, H. (2014). The Violence of Organized Forgetting: Thinking Beyond America's Disimagination Machine. San Francisco, CA: City Lights Books.

Goldman, D. (2012). Ecoliterate: How Educators are Cultivating Emotional, Social, and Ecological Intelligence. San Francisco, CA: Jossey Bass.

Habiba, U., Abedin, M., and Shaw, R. (2013). "Defining water insecurity," in Water Insecurity: A Global Dilemma, eds R. Shaw, H. Umma, and M. Abedin (Bingley: Emerald Group Publishing), 3-22.

Heath, S. B. (2013). "Theories of reading in the worlds of childhood and adolescence," in Theoretical Models and Processes of Reading, 6th Edn., eds D. Alvermann, N. Unrau, and R. Ruddell (Newark, DE: International Reading Association), 204-227.

Hmelo-Silver, C. E., Marathe, S., and Liu, L. (2007). Fish swim, rocks sit, and lungs breathe: expert-novice understanding of complex systems. J. Learn. Sci. 16, 307-331. doi: 10.1080/10508400701413401

Hokayem, H., and Gotwals, A. W. (2016). Early elementary students understanding of complex ecosystems: a learning progression approach. J. Res. Sci. Teach. 53, 1524-1545. doi: 10.1002/tea.21336

Hokayem, H., Ma, J., and Jin, H. (2015). A learning progression for feedback loop reasoning at lower elementary level. J. Biol. Educ. 49, 246-260. doi: 10.1080/00219266.2014.943789

Koski, M., and deVries, M. (2013). An exploratory study on how primary pupils approach systems. Sci. Educ. Commun. 23, 835-848. doi: 10.1007/s10798-013-9234-z

Lammi, M., and Becker, K. (2013). Engineering design thinking. J. Technol. Educ. 24, 55-77. doi: 10.21061/jte.v24i2.a.5

Layton, L. (2015), July 18. The Specter of 'President Donald Trump' Dooms Climate ed Change Grants. Washington Post. Available online at: http:// 
www.washingtonpost.com/local/education/the-specter-of-president-trumpdooms-climate-change-ed-grants/2015/07/15/8a969df2-2b28-11e5-a5eacf74396e59ec_story.html (Accessed July 18, 2015).

MacLachlan (1985). Sarah, Plain and Tall (1985), Patricia MacLachlan. New York, NY: HarperCollins.

MacLachlan (2001). Caleb's Story (2001) Patricia MacLachlan. New York, NY: HarperCollins.

Mambondiyani, A. (2017). As Droughts Lengthen, Zimbabwe's Medicinal Plants Disappear. In Reuters. Available online at: https://www.reuters.com/article/uszimbabwe-drought-medicine/as-droughts-lengthen-zimbabwes-medicinalplants-disappear-idUSKBN1DR24F

Mapping the Devastation of Somalia's Drought (2018), January 30. In United Nations Environment. Available online at: https://www.unenvironment.org/ news-and-stories/story/mapping-devastation-somalias-drought (Accessed January 30, 2018).

McKibben, B. (2012), July 19. Global Warming's Terrifying New Math. Rolling Stone Magazine. Available online at: http://www.rollingstone.com/politics/ news/global-warmings-terrifying-new-math-20120719 (Accessed August 28, 2018).

Meadows, D. H. (Eds). (2008). Thinking in systems: A primer. White River Junction, VT: Chelsea Green Publishing.

Montana-Hoyos, C., and Lenmire, F. (2011). Systems thinking, disciplinarity, and critical thinking in relation to creativity within contemporary arts and design education. Stud. Learn. Eval. Innov. Dev. 8, 12-25.

Opfer, V. D., and Pedder, D. (2011) Conceptualizing teacher professional learning. Rev. Educ. Res. 81, 376-407. doi: 10.3102/0034654311413609

Senge, P. (2007). "Give me a Lever long enough... and single-handed I can move the world," in Educational Leadership, 2nd Edn. San Francisco, CA: John Wiley \& Sons.

Senge, P., Cambron-McCabe, N., Lucas, T., Smith, B., Dutton, J., and Kleiner, A. (2012). Schools that Learn: A Fifth Discipline Fieldbook for Educators, Parents, and Everyone Who Cares About Education. New York, NY: Crown Business.

Sheehy, N. P., Wylie, J. W., McGuinness, C., and Orchard, G. (2000). How children solve environmental problems: using computer simulations to investigate system thinking. Environ. Educ. Res. 6, 109-126. doi: 10.1080/713 664675

Skelton, G. (2014). Coalition Forms to Manage California's Groundwater. Los Angeles Times. Available online at: http://www.latimes.com/local/politics/lame-cap-ground-water-20140721-column.html (Accessed July 21, 2015).
Strachan, G. (2009). "Systems thinking: the ability to recognize and analyse the interconnections within and between systems," in The Handbook of Sustainability Literacy, eds A. Stribbe (Devon: Green Books), 84-88.

Stribbe, A. (2009). The Handbook of Sustainability Literacy. Devon: Green Books.

Sweeney, L. B., and Sterman, J. D. (2007). Thinking about systems: student and teacher conceptions of natural and social systems. Syst. Dyn. Rev. 23, 285-312. doi: $10.1002 /$ sdr.366

Tharp, R., and Gallimore, R. (1988). Rousing Minds to Life. New York, NY: Cambridge University Press.

Vygotsky, L. S. (1938/1987). The Collected Works of L. S. Vygotsky, Vol. 1, Problems of General Psychology. Transl. By N. Minick and edited by R. W. Riber and A. S. Carton. New York, NY: Plenum Press.

Wheatley, M. J. (2006). Leadership and the New Science, 3rd Edn. San Francisco, CA: Berrett-Koehler Publishers.

White (1952). Charlotte's Web (1952) E. B. White. New York, NY: HarperCollins.

Wolf, A. (2012). "Water Wars and Peace," in Ecoliterate: How educators are Cultivating Emotional, Social, and Ecological Intelligence, eds D. Goleman, L. Bennett, and Z. Barlow (San Francisco, CA: Jossey-Bass), 65-75.

World Water Council (March, 2018). World Leaders and Thousands of Experts Gather at the Opening of the 8th World Water Forum. Available online at: http://www.worldwatercouncil.org/en/world-leaders-and-thousands-expertsgather-opening-8th-world-water-forum (Accessed September 29, 2018).

Yin, R. K. (2014). Case Study Research: Design and Methods, 5th Edn. Los Angeles, CA: Sage Publications.

Yoon, S. A., Goh, S.-E., and Park, M. (2017). Teaching and learning about complex systems in K-12 science education: a review of empirical studies 1995-2015. Rev. Educ. Res. 88:0034654317746090. doi: 10.3102/0034654317746090

Conflict of Interest Statement: The authors declare that the research was conducted in the absence of any commercial or financial relationships that could be construed as a potential conflict of interest.

Copyright (C) 2018 Curwen, Ardell, MacGillivray and Lambert. This is an open-access article distributed under the terms of the Creative Commons Attribution License (CC BY). The use, distribution or reproduction in other forums is permitted, provided the original author(s) and the copyright owner(s) are credited and that the original publication in this journal is cited, in accordance with accepted academic practice. No use, distribution or reproduction is permitted which does not comply with these terms. 